\title{
Different approaches to the synthesis of ZSM-22 zeolite with application in n-heptane cracking
}

\author{
Diferentes abordagens de síntese da zeólita ZSM-22 com aplicação no craqueamento do n-heptano
}

Diferentes enfoques para la síntesis de zeolita ZSM-22 con aplicación al craqueo de n-heptano

Received: 01/23/2022 | Reviewed: 02/01/2022 | Accept: 02/06/2022 | Published: 02/12/2022

Lenivaldo Valério de Sousa Júnior

ORCID: https://orcid.org/0000-0001-7512-0646

Federal University of Pernambuco, Brazil

E-mail: lenivaldovalerio@ hotmail.com

Thaís Regina Silva Ribeiro

ORCID: https://orcid.org/0000-0002-3392-8070

Federal University of Bahia, Brazil

E-mail: thaisreginasilvar@outlook.com

Bruno José Barros da Silva

ORCID: https://orcid.org/0000-0002-0297-9588

Federal University of Alagoas, Brazil

E-mail: brunojbarros@hotmail.com

Paulo Henrique Leite Quintela

ORCID: https://orcid.org/0000-0003-0881-0852

Federal University of Sergipe, Brazil

E-mail: pauloquintela1984@gmail.com

Soraya Lira Alencar

ORCID: https://orcid.org/0000-0001-5945-5809

Federal University of Alagoas, Brazil

E-mail: soraya.alencar@gmail.com

José Geraldo de Andrade Pacheco Filho

ORCID: https://orcid.org/0000-0002-8812-5021

Federal University of Pernambuco, Brazil

E-mail: jose.pacheco@ufpe.br

Antonio Osimar Sousa da Silva

ORCID: https://orcid.org/0000-0002-6524-8571

Federal University of Alagoas, Brazil

E-mail: antonio.silva@ctec.ufal.br

\begin{abstract}
The synthesis of ZSM-22 zeolite has been extensively studied due to its properties of form selectivity, acidity and hydrothermal stability, which is applied in important reactions in the areas of petroleum refining and petrochemicals. In view of this, the present work studied different approaches of synthesis of ZSM-22 using: 1-diaminohexane as a structure directing agent, (ii) methanol and seed crystals, (iii) aging of the synthesis gel with addition of polymer, surfactant and silane and (iv) starch, calcium carbonate and silanized silica with subsequent desilication. Thus, the effects of these methodologies on the textural properties, acidity and catalytic activity of the zeolites obtained were evaluated. The samples were characterized by X-ray diffraction (XRD), nitrogen adsorption-desorption, scanning electron microscopy (SEM), ammonia desorption at programmed temperature $\left(\mathrm{NH}_{3}-\mathrm{TPD}\right)$ and thermal analysis (TG/DTG). The catalytic activity and selectivity of the catalysts were evaluated in the model catalytic cracking reaction of n-heptane at $650{ }^{\circ} \mathrm{C}$ for $180 \mathrm{~min}$. The synthesis route using methanol and seed crystals allowed obtaining ZSM-22 in $3 \mathrm{~h}$ of crystallization, drastically reducing the synthesis time compared to other methodologies. Despite this, the use of 1-diaminohexane led to the obtaining of zeolite with textural properties, acidity and catalytic activity superior to the other samples. The generation of mesoporosity was obtained through the use of silanized silica and subsequent desilication, leading to greater catalytic stability and less deactivation by coke. All catalysts showed similar selectivity to the formation of compounds in the range $\mathrm{C} 2$ to $\mathrm{C} 4$.
\end{abstract}

Keywords: ZSM-22; Zeolite; Different synthesis approaches; Catalytic cracking.

\section{Resumo}

A síntese da zeólita ZSM-22 tem sido extensivamente estudada devido às suas propriedades de seletividade de forma, acidez e estabilidade hidrotérmica, sendo esta aplicada em reações na área petroquímica. Diante disto, o presente objetivou estudar diferentes abordagens de síntese da ZSM-22 utilizando: (i) 1-diaminohexano como agente 
Research, Society and Development, v. 11, n. 3, e6411326070, 2022

(CC BY 4.0) | ISSN 2525-3409 | DOI: http://dx.doi.org/10.33448/rsd-v11i3.26070

direcionador de estrutura, (ii) metanol e cristais sementes, (iii) envelhecimento do gel de síntese com adição de polímero, surfactante e silano e (iv) amido, carbonato de cálcio e sílica silanizada com posterior dessilicação. Com isso foram avaliados os efeitos destas metodologias sob as propriedades texturais, acidez e atividade catalítica das zeólitas obtidas. As amostras foram caracterizadas pelas técnicas de difratometria de raios X (DRX), adsorçãodessorção de nitrogênio, microscopia eletrônica de varredura (MEV), dessorção de amônia a temperatura programada (TPD-NH3) e análises térmicas (TG/DTG). A atividade catalítica e a seletividade dos catalisadores foram avaliadas na reação modelo de craqueamento catalítico do n-heptano a $650{ }^{\circ} \mathrm{C}$ por $180 \mathrm{~min}$. A rota de síntese utilizando metanol e cristais sementes permitiu a obtenção da ZSM-22 em $3 \mathrm{~h}$ de cristalização, reduzindo o tempo de síntese drasticamente frente às outras metodologias. Apesar disto, a utilização do 1-diaminohexano levou a obtenção da ZSM-22 com propriedades texturais, acidez e atividade catalítica superiores às das demais amostras. A geração de mesoporosidade foi obtida por meio do uso de sílica silanizada e posterior dessilicação, levando a uma maior estabilidade catalítica e menor desativação por coque. Todos os catalisadores demonstraram seletividade similar à formação de compostos na faixa C2 a C4.

Palavras-chave: ZSM-22; Zeólita; Diferentes abordagens de síntese; Craqueamento catalítico.

\begin{abstract}
Resumen
La síntesis de la zeolita ZSM-22 ha sido ampliamente estudiada debido a sus propiedades de selectividad de forma, acidez y estabilidad hidrotermal, la cual se aplica en importantes reacciones en las áreas de refinación de petróleo y petroquímica. En vista de esto, el presente trabajo estudió diferentes enfoques de síntesis de ZSM-22 utilizando: (i) 1diaminohexano como agente director de estructura, (ii) metanol y cristales semilla, (iii) envejecimiento del gel de síntesis con adición de polímero, surfactante y silano, y (iv) aplicando almidón, calcio carbonato y sílice silanizada con posterior desilicación. Así, se evaluaron los efectos de estas metodologías sobre las propiedades texturales, acidez y actividad catalítica de las zeolitas obtenidas. Las muestras se caracterizaron por difracción de rayos X (DRX), adsorción-desorción de nitrógeno, microscopía electrónica de barrido (MEB), desorción de amoníaco a temperatura programada ( $\mathrm{NH}_{3}$-TPD) y análisis térmico (TG/DTG). La actividad catalítica y la selectividad de los catalizadores se evaluaron en el modelo de reacción de craqueo catalítico de n-heptano a $650{ }^{\circ} \mathrm{C}$ durante 180 min. La ruta de síntesis utilizando metanol y cristales semilla permitió obtener ZSM-22 en 3 h de cristalización, reduciendo drásticamente el tiempo de síntesis en comparación con otras metodologías. A pesar de esto, el uso de 1-diaminohexano condujo a la obtención de una zeolita con propiedades texturales, acidez y actividad catalítica superior a las otras muestras. La generación de mesoporosidad se obtuvo mediante el uso de sílice silanizada y posterior desilicación, lo que condujo a una mayor estabilidad catalítica y una menor desactivación por coque. Todos los catalizadores mostraron una selectividad similar para la formación de compuestos en el rango de C2 a C4.
\end{abstract}

Palabras clave: ZSM-22; Zeolita; Diferentes enfoques de síntesis; Craqueo catalítico.

\title{
1. Introduction
}

ZSM-22 is a silicon-rich zeolite, formed by non-intersecting one-dimensional channels with an opening diameter of 0.57 and $0.46 \mathrm{~nm}$, comprised of 5, 6 and 10 membered rings. The channels are directed to the longest dimension of the crystals (crystallographic direction c) (Del Campo, et al., 2018). Due to the narrow pore size, ZSM-22 exhibits shape selective effect in different reactions, such as hydroisomerization dewaxing (Gao, et al., 2020), propene oligomerization (Redekop, et al., 2020; Dagle, et al., 2020) and methanol-to-hydrocarbons (MTH) (Liu, et al., 2017).

Valyocsik reported in a 1984 patent the first synthesis of ZSM-22 zeolite using alkanediamines in the C2-C12 range as structure-directing agents. The ZSM-22 standard synthesis method published by the Synthesis Commission of the International Zeolite Association (Robson et al., 2001), adopts 1,8-diaminoethane as OSDA, with prior aging of the synthesis gel for $24 \mathrm{~h}$ at room temperature, and subsequent crystallization at $160{ }^{\circ} \mathrm{C}$ for 2 to 3 days, under vigorous stirring (400 rpm). In low-stirring (less than $400 \mathrm{rpm}$ ) or static synthesis systems, other phases such as the MEL zeolite (Valyocsik, 1984; Robson \& Lillerud, 2001), ZSM-5 zeolite and cristobalite (Verduijn et al., 1996) are obtained.

Different parameters affect the crystallization and physicochemical properties of a specific zeolitic phase, such as synthesis method, chemical composition of the initial gel, type of reagents, synthesis gel $\mathrm{SiO}_{2} / \mathrm{Al}_{2} \mathrm{O}_{3}$ ratio, alkalinity, water content, inorganic cations, organic directing organic structure-directing agents, temperature, aging of the synthesis gel, stirring and use of seed crystals (Yu, 2007; Shin et al.,2019). Rollmann et al. (1999) describe in their study the relationship between the structure of small amines and the zeolitic phase obtained. For a $\mathrm{SiO}_{2} / \mathrm{Al}_{2} \mathrm{O}_{3}$ ratio of equal to 200, certain acyclic amines 
Research, Society and Development, v. 11, n. 3, e6411326070, 2022

(CC BY 4.0) | ISSN 2525-3409 | DOI: http://dx.doi.org/10.33448/rsd-v11i3.26070

were specific for the formation of 10-ring zeolites, as ethylmethylamine and diethylamine produced ZSM-22, while ethylamine and isopropylamine resulted in ZSM-23 zeolite. Accordingly, larger molecular size cyclic amines such as piperazine have produced zeolites with a 12-ring pore system such as ZSM-12. For synthesis gels with $\mathrm{SiO}_{2} / \mathrm{Al}_{2} \mathrm{O}_{3}$ ratios below 40 , different zeolites were produced, such as ZSM-35 and MCM-22, showing a specific relationship between the amine employed and the zeolite obtained.

Wen et al. (2014) presented a study of the synthesis of pure-silica ZSM-22 by the dry gel conversion method. The gel was prepared in an acidic medium to hydrolyze the silica precursor, and the ionic liquid 1,3-alkylimidazolium was used as organic structure-directing agent. The pure-silica ZSM-22 structure was obtained within 2 days of crystallization. Using a similar procedure, the synthesis of Al-containing ZSM-22 was studied by adding aluminum salt to the starting gel. Lopes et al. (2016) reported the synthesis of the Al-TON structure using 1-butyl-3-methylimidazolium chloride as OSDA. This organic cation showed greater efficiency and selectivity for the synthesis of TON zeolites under different reaction conditions compared to 1,8-diaminooctane (a traditional OSDA). The scanning electron microscopy technique indicated that zeolites with different crystal sizes were obtained under static or stirred synthesis (static method from 30 to $50 \mu \mathrm{m}$ and stirred method less than 2 $\mu \mathrm{m})$, which consequently affects the textural properties of the zeolites.

Jamil et al., (2016) described the crystallization of ZSM-22 through the microwave solvothermal synthesis method, evaluating the effect of the type and amount of different co-solvents, such as ethanol, 2-propanol, glycerol, ethylene glycol and the aging time of the synthesis gel. They found that a long aging time $(72 \mathrm{~h})$ was crucial to obtain smaller and more uniform crystals. The addition of a co-solvent resulted in more elongated crystals, and the crystallinity of the zeolite was sensitive to the type of co-solvent. In general, the use of a co-solvent led to the formation of ZSM-5 zeolite as an impurity, which is proportional to the concentration of the co-solvent in the reaction medium.

Sousa et al (2017) studied the effect of crystallization time, use of seed crystals, methanol as solvent, variation of the $\mathrm{SiO}_{2} / \mathrm{Al}_{2} \mathrm{O}_{3}$ and $\mathrm{OH}^{-} / \mathrm{SiO}_{2}$ ratios, the addition of potassium and stirring on the properties of ZSM-22 zeolite. Under static condition and $\mathrm{SiO}_{2} / \mathrm{Al}_{2} \mathrm{O}_{3}$ ratio of $100, \mathrm{ZSM}-22$ was obtained after $6 \mathrm{~h}$, in the presence of methanol, $\mathrm{OH}^{-} / \mathrm{SiO}_{2} \mathrm{ratio}$ of 0.2 and without addition of potassium. With the $\mathrm{SiO}_{2} / \mathrm{Al}_{2} \mathrm{O}_{3}$ ratio of 50 , the increase in alkalinity $\left(\mathrm{OH}^{-} / \mathrm{SiO}_{2} \mathrm{ratio}=0.4\right)$ or in the potassium content resulted in a decrease in the crystallinity of the zeolite. The stirred synthesis with $\mathrm{SiO}_{2} / \mathrm{Al}_{2} \mathrm{O}_{3}$ ratio of 100 and low methanol content increased the crystallinity and specific surface area of the zeolite, reducing the crystallization time to $3 \mathrm{~h}$.

Jamil et al. (2014) reported the synthesis of nanometric ZSM-22 after $72 \mathrm{~h}$ of synthesis gel aging at $50{ }^{\circ} \mathrm{C}$ and crystallization by the microwave method for $12 \mathrm{~h}$ at $180{ }^{\circ} \mathrm{C}$. The nonionic polyoxyethylene surfactant - Brij-76 was added to the reaction medium and led to a decrease in size (between $90-300 \mathrm{~nm}$ ) and agglomeration of the crystals, as well as the formation of competing phases. A better catalytic activity in the n-hexane cracking was observed for the catalysts with shorter crystal length $(90 \mathrm{~nm})$ in comparison to the larger ones $(300 \mathrm{~nm})$. This fact was attributed to the higher external surface area and the smaller length of the crystals, which offers more accessibility to the pores of the zeolitic structure (Rownaghi, Rezaei \& Hedlund, 2012).

Due to the microporous structure of zeolites, especially those with one-dimensional pore systems such as ZSM-22, there is a diffusional resistance to bulky reagents and products (kinetic diameter greater than $1.4 \mathrm{~nm}$ ) to the internal acid sites of the zeolite structure. Therefore, different studies have been carried out with the aim of improving the textural properties of these materials with the introduction of a secondary porosity (Verboekend, et al., 2011; Dyballa, et al., 2016; Del Campo, et al., 2018; Wang et al.,2019). Silva et al. (2019) obtained the micro-mesoporous ZSM-22 by adding nanometric silica previously silanized with trimethoxyphenylsilane to the reaction mixture, followed by desilication. The samples showed a pore 
size distribution in the range of mesopores between 40 and $60 \mathrm{~nm}$.

Zhu et al. (2008) synthesized hierarchical silicalite-1 (mesopores in the range of $50-100 \mathrm{~nm}$ ) using nanometric carbonate $\left(\mathrm{CaCO}_{3}\right)$ as a hard template for secondary porosity. After crystallization $\left(140{ }^{\circ} \mathrm{C}\right.$ for 7 days $)$ the material was washed with $\mathrm{HCl}$ solution to remove the carbonate and consequently generate the mesopores. Zhang, Liu \& Yan (2016) described the synthesis of mesoporous ZSM-5 using carbonized soluble starch. The zeolite showed high thermal and hydrothermal stability, with irregular mesopores distribution due to the different dimensions of the carbonized starch. After crystallization $\left(170{ }^{\circ} \mathrm{C}\right.$ for 5 days), carbon was removed by calcination at $800{ }^{\circ} \mathrm{C}$.

The catalytic cracking of hydrocarbons on acidic solid catalysts involves a large number of process parameters and variables related to the reaction conditions and the physicochemical properties of the catalyst and hydrocarbon molecules. The difficulties to optimize catalytic cracking processes in order to obtain specific products are mainly due to: (i) catalyst deactivation with residence time, via coke formation, and (ii) the presence of a large number of reaction steps and products (Corma, et al., 2005; Rahimi et al.,2011; Corma, et al., 2017).

Given the above, systematic studies on a laboratory scale are commonly carried out using some low molecular weight hydrocarbons, such as n-heptane, as a representative of the feed charge (vacuum diesel) of the fluidized catalytic cracking process, enabling the determination of kinetic parameters, development of reaction mechanisms, catalyst designs and validation, adjustment and/or optimization of cracking units (Blay, et al., 2017; Afroukhteh-Langaroudi, Tarighi et al., 2018; Xu, et al., 2018).

In this context, the objective of this work was to evaluate the synthesis of ZSM-22 zeolite by different methodologies, using: (i) 1-diaminohexane as a structure-directing agent, (ii) methanol and seed crystals, (iii) gel aging of synthesis with addition of polymer, surfactant and silane, (iv) starch, calcium carbonate and silanized silica, with subsequent desilication, and thus evaluate the effects of these methodologies on the textural properties, acidity and catalytic activity in the catalytic cracking of n-heptane of the obtained zeolites.

\section{Methodology}

\subsection{Synthesis of the ZSM-22 zeolite}

\subsubsection{Synthesis using 1,6-diaminohexane as structure-directing agent}

The reagents were added in stoichiometric proportions in order to obtain a mixture with the following molar composition: $27.0 \mathrm{NH}_{2}\left(\mathrm{CH}_{2}\right)_{6} \mathrm{NH}_{2}: 13.5 \mathrm{~K}_{2} \mathrm{O}: 1.0 \mathrm{Al}_{2} \mathrm{O}_{3}: 90.0 \mathrm{SiO}_{2}: 3600 \mathrm{H}_{2} \mathrm{O}$ (Valyocsik, 1984). The preparation of the reaction mixture consisted of the following steps: (i) dissolution of potassium hydroxide (Sigama-Aldrich, $85 \%$ ) in $30 \%$ of the total amount of water required for synthesis (Solution A), (ii) dissolution of 1,6-diaminohexane (Sigma-Aldrich, 98\%) in 30\% of the water required for synthesis (Solution B), (iii) solubilization of aluminum sulphate (Merck, 99\%) in 30\% of the water required for synthesis, with sulfuric acid being subsequently added dropwise (J.T. Baker, 98\%) (Solution C) and (iv) dispersion of colloidal silica (Ludox-AS-40, Sigma-Aldrich, 40\%) in 10\% of the water required for synthesis (Solution D). Subsequently, solution B was mixed with solution A, under mechanical stirring at $200 \mathrm{rpm}$ for $10 \mathrm{~min}$. Then, solution $\mathrm{C}$ was added under mechanical stirring at $200 \mathrm{rpm}$ for $10 \mathrm{~min}$. Finally, solution D was added under mechanical stirring at $200 \mathrm{rpm}$ for $30 \mathrm{~min}$. The hydrothermal treatment of the gel was carried out at $160{ }^{\circ} \mathrm{C}$ in a $1 \mathrm{~L}$ Parr Instrument Company stirred reactor (model 4520 ), under agitation at $400 \mathrm{rpm}$ for $17 \mathrm{~h}$. The solid was recovered by vacuum filtration, washed until neutral $\mathrm{pH}$, and then dried in an oven at $120{ }^{\circ} \mathrm{C}$ for $12 \mathrm{~h}$ (Z22-ADE Sample). 
Research, Society and Development, v. 11, n. 3, e6411326070, 2022

(CC BY 4.0) | ISSN 2525-3409 | DOI: http://dx.doi.org/10.33448/rsd-v11i3.26070

\subsubsection{Synthesis using methanol as a co-solvent}

The molar composition used to obtain the synthesis gel was $9.0 \mathrm{CH}_{3} \mathrm{OH}: 0.3 \mathrm{Na}_{2} \mathrm{O}: 1.0 \mathrm{Al}_{2} \mathrm{O}_{3}: 90.0 \mathrm{SiO}_{2}: 20.0 \mathrm{H}_{2} \mathrm{O}$ (Morimoto, Takatsu \& Sugimoto, 1983). The gel was prepared through the following steps: (i) dilution of sulfuric acid (J. T. Baker, $98 \%$ ) in $25 \%$ of the total amount of water required for synthesis (Solution A), (ii) solubilization of aluminum sulfate (Merck, 99\%) in 25\% of the water required for synthesis (Solution B), (iii) dilution of sodium silicate (Pernambuco Química PQ-4, $10.07 \% \mathrm{Na} 2 \mathrm{O}, 32.22 \% \mathrm{SiO}_{2}$ ) in $25 \%$ of the water required for synthesis (Solution $\mathrm{C}$ ) and (iv) dilution of methanol (Synth, $99 \%$ ) in $25 \%$ of the water required for synthesis (Solution D). Then, solution B was mixed with solution A, under mechanical stirring at $200 \mathrm{rpm}$ for $10 \mathrm{~min}$. Subsequently, solution C was added under mechanical stirring at $200 \mathrm{rpm}$ for 60 min. Finally, solution D was added under mechanical stirring at $200 \mathrm{rpm}$ for $60 \mathrm{~min}$. The crystallization was carried out at 170 ${ }^{\circ} \mathrm{C}$ in a $1 \mathrm{~L}$ Parr Instrument Company stirred reactor (model 4520), under agitation at $400 \mathrm{rpm}$ for $20 \mathrm{~h}$. Subsequently, the final solid was separated by vacuum filtration, washed to neutral $\mathrm{pH}$, and dried in an oven at $120{ }^{\circ} \mathrm{C}$ for $12 \mathrm{~h}$ (Z22-Me Sample).

\subsubsection{Synthesis using seed crystals and methanol as co-solvent}

The molar composition of the synthesis gel was $27.0 \mathrm{NH}_{2}\left(\mathrm{CH}_{2}\right)_{6} \mathrm{NH}_{2}: 13.5 \mathrm{~K}_{2} \mathrm{O}: 1.0 \mathrm{Al}_{2} \mathrm{O}_{3}: 90.0 \mathrm{SiO}_{2}: 4.5 \mathrm{H}_{2} \mathrm{SO}_{4}: 3600 \mathrm{H}_{2} \mathrm{O}$ $+10 \%$ of seed crystals (mass percentage in relation to the amount of silica) (Sousa, et al., 2017). The mixing steps were: (i) dilution of sulfuric acid (J. T. Baker, 98\%) in 20\% of the total amount of water required for synthesis (Solution A), (ii) solubilization of aluminum sulfate in $20 \%$ of the water required for synthesis (Solution B), (iii) dilution of sodium silicate in $20 \%$ of the water required for synthesis (Solution C), (iv) methanol dilution in $20 \%$ of the water required for synthesis (Solution D) and (v) dispersion of ZSM-22 seed crystals (sample Z22-ADE, previously synthesized) in $20 \%$ of the water required for synthesis (Solution $\mathrm{E}$ ) . In sequence, solution B was mixed with solution $\mathrm{A}$, and subsequently the solutions $\mathrm{C}$ and D were added, with each step under mechanical stirring at $200 \mathrm{rpm}$ for $10 \mathrm{~min}$. Finally, solution E was added under mechanical stirring at $200 \mathrm{rpm}$ for $30 \mathrm{~min}$. The synthesis process was carried out at $170{ }^{\circ} \mathrm{C}$ in a $1 \mathrm{~L}$ Parr Instrument Company stirred reactor (model 4520), under agitation at $400 \mathrm{rpm}$ for $3 \mathrm{~h}$. After this period, the final solid was separated by vacuum filtration, washed to neutral $\mathrm{pH}$, and oven dried at $120{ }^{\circ} \mathrm{C}$ for $12 \mathrm{~h}$ (Z22-Me-CS Sample).

\subsubsection{Synthesis through gel aging using polymer, surfactant and silane}

The synthesis was carried out using a two-step procedure: (i) aging of the synthesis gel and (ii) crystallization. The molar composition $27.0 \mathrm{NH}_{2}\left(\mathrm{CH}_{2}\right)_{6} \mathrm{NH}_{2}: 13.5 \mathrm{~K}_{2} \mathrm{O}: 1.0 \mathrm{Al}_{2} \mathrm{O}_{3}: 90.0 \mathrm{SiO}_{2}: 4.5 \mathrm{H}_{2} \mathrm{SO}_{4}: 3600 \mathrm{H}_{2} \mathrm{O}: 2.5(\mathrm{X}$ or $\mathrm{Y}$ or $\mathrm{Z})($ where $\mathrm{X}=$ polymer, $\mathrm{Y}=$ surfactant and $\mathrm{Z}=$ silane) and methodology of the synthesis gel preparation for the aging stage was similar to those used for the Z22-ADE sample (topic 2.1.1). The synthesis gel was aged for $20 \mathrm{~h}$ at $120{ }^{\circ} \mathrm{C}$, under stirring at $200 \mathrm{rpm}$ in a $300 \mathrm{~mL}$ Parr Instrument Company stirred reactor (model 4566). Then, the gel was divided into equal parts, to which were added, under mechanical stirring at $200 \mathrm{rpm}$ for $30 \mathrm{~min}$, Pluronic P123 polymer (Sigma-Aldrich, 99\%), Brij93 surfactant (Sigma-Aldrich, 99\%), and vinyltrimethoxysilane silane (Sigma-Aldrich, 98\%). Each gel was transferred to the same reactor as in the aging step. Crystallization was carried out under stirring at $400 \mathrm{rpm}$ at a temperature of $160{ }^{\circ} \mathrm{C}$ for $20 \mathrm{~h}$. After crystallization, the final solid was recovered by vacuum filtration, washed to neutral $\mathrm{pH}$, and oven dried at $120{ }^{\circ} \mathrm{C}$ for $12 \mathrm{~h}$ (Z22-P123, Z22-Brij93 and Z22-Vynil Samples).

\subsubsection{Synthesis using soluble starch}

The molar composition used was similar to that of the Z22-ADE sample plus a percentage by mass of starch in relation to the mass of silica: $27.0 \mathrm{NH}_{2}\left(\mathrm{CH}_{2}\right)_{6} \mathrm{NH}_{2}: 13.5 \mathrm{~K}_{2} \mathrm{O}: 1.0 \mathrm{Al}_{2} \mathrm{O}_{3}: 90.0 \mathrm{SiO}_{2}: 4.5 \mathrm{H}_{2} \mathrm{SO}_{4}: 3600 \mathrm{H}_{2} \mathrm{O}+1.5 \mathrm{Starch} / \mathrm{SiO}_{2}(\mathrm{ratio}$ of 
Research, Society and Development, v. 11, n. 3, e6411326070, 2022

(CC BY 4.0) | ISSN 2525-3409 | DOI: http://dx.doi.org/10.33448/rsd-v11i3.26070

1.5 times the amount of starch to silica, by mass) (Zhang, Liu \& Yan, 2016). The synthesis gel preparation procedure was carried out in the following steps: (i) dissolution of aluminum sulphate (Merck, 99\%) in 25\% of the water required in the synthesis, followed by dropwise addition of sulfuric acid (J. T. Baker, 98\%) (Solution A), (ii) dispersion of the soluble starch (Sigma-Aldrich, 99\%) in 25\% of the water required for synthesis. Solution A was mixed with solution B, under stirring at 200 rpm for $10 \mathrm{~min}$. Then, colloidal silica (Ludox-AS-40, Sigma-Aldrich, 40\%) was added to the previous mixture, under stirring at $200 \mathrm{rpm}$ for $10 \mathrm{~min}$, obtaining a paste in which the starch is highly dispersed.

This paste was transferred to a $100 \mathrm{~mL}$ teflon vessel, which was placed in a $300 \mathrm{~mL}$ Parr Instrument Company stirred reactor (model 4566), and heated at $60{ }^{\circ} \mathrm{C}$ for $4 \mathrm{~h}$ under agitation at $300 \mathrm{rpm}$. After the heat treatment, a (black) solid was obtained which was ground. Then, the resulting solid was carbonized in a muffle oven at $170{ }^{\circ} \mathrm{C}$ for $17 \mathrm{~h}$. Subsequently, (iii) dissolution of 1,6-diaminohexane in 30\% of the water required for synthesis (Solution C) and (iv) dissolution of KOH in $20 \%$ of the water required for synthesis (Solution D). Solution D was added to solution C, under stirring at $200 \mathrm{rpm}$ for $10 \mathrm{~min}$. The carbonized solid was then added to the previous mixture, under stirring at $200 \mathrm{rpm}$ for $30 \mathrm{~min}$, and this new mixture was submitted to hydrothermal treatment, in the same Parr reactor described above, at $80^{\circ} \mathrm{C}$ for $2 \mathrm{~h}$. The final solid was washed to neutral $\mathrm{pH}$ and separated by vacuum filtration, and then oven dried at $120^{\circ} \mathrm{C}$ for $12 \mathrm{~h}$ (Z22-Starch-Cal sample).

\subsubsection{Synthesis using calcium carbonate}

The stoichiometric molar composition of the synthesis gel $9.0 \mathrm{CH}_{3} \mathrm{OH}: 0.3 \mathrm{Na}_{2} \mathrm{O}: 1.0 \mathrm{Al}_{2} \mathrm{O}_{3}: 90.0 \mathrm{SiO}_{2}: 20.0 \mathrm{H}_{2} \mathrm{O}+0.16$ $\mathrm{CaCO}_{3} / \mathrm{SiO}_{2}$ (ratio of 0.16 times the amount of $\mathrm{CaCO}_{3}$ to silica, by mass) (Zhu, et al., 2008), and the preparation procedure adopted were similar to that described for the Z22-Me sample (topic 2.1.2). Calcium carbonate was added at the end of the preparation of the reaction mixture, under mechanical stirring at $200 \mathrm{rpm}$ for $30 \mathrm{~min}$. Crystallization was carried out at $170{ }^{\circ} \mathrm{C}$ for $20 \mathrm{~h}$. Then, the resulting solid was submitted to an acid treatment with a $0.5 \mathrm{~mol} \mathrm{~L}^{-1}$ hydrochloric acid solution (Neon, $37 \%$ ), under mechanical stirring at $100 \mathrm{rpm}$ for $30 \mathrm{~min}$, to remove the $\mathrm{CaCO}_{3}$. The ratio of $3 \mathrm{~g}$ of solid per $30 \mathrm{~mL}$ of solution was used. Finally, the material was washed to neutral $\mathrm{pH}$ by vacuum filtration and dried at $120{ }^{\circ} \mathrm{C}$ for $12 \mathrm{~h}$ (sample Z22$\mathrm{CaCO} 3-\mathrm{HCl})$.

\subsubsection{Synthesis using silanized silica}

The molar composition of the synthesis gel $27.0 \mathrm{NH}_{2}\left(\mathrm{CH}_{2}\right)_{6} \mathrm{NH}_{2}: 13.5 \mathrm{~K}_{2} \mathrm{O}: 1.0 \mathrm{Al}_{2} \mathrm{O}_{3}: 90.0 \mathrm{SiO}_{2}$ ( $-20 \%$ by mass):4.5 $\mathrm{H}_{2} \mathrm{SO}_{4}: 3600 \mathrm{H}_{2} \mathrm{O}+20 \%$ silanized silica (percentage by mass, in relation to $\mathrm{SiO}_{2}$ ) ( $\mathrm{Silva}$, et al., 2018) was similar to that described for the Z22-ADE sample (topic 2.1.1). 20\% of the colloidal silica (Ludox-HS-40, Sigma-Aldrich, 40\%) required for the synthesis were previously separated, which was mixed with a solution of $2.5 \mathrm{~g}$ of silane in $40 \mathrm{~mL}$ of water, and this mixture was then dried in an oven for $12 \mathrm{~h}$ at $110{ }^{\circ} \mathrm{C}$. After this time, the solid obtained was added to the synthesis gel, under mechanical stirring at $200 \mathrm{rpm}$ for $10 \mathrm{~min}$. The hydrothermal treatment of the gel was carried out at $160{ }^{\circ} \mathrm{C}$ in a $1 \mathrm{~L}$ Parr Instrument Company stirred reactor (model 4520), under agitation at $400 \mathrm{rpm}$ for $20 \mathrm{~h}$.

Subsequently, the resulting solid was submitted to an alkaline treatment with a sodium hydroxide solution (Merck, $98 \%$ ) of $0.1 \mathrm{~mol} \mathrm{~L}^{-1}$ at $80^{\circ} \mathrm{C}$ for $2 \mathrm{~h}$. The ratio of $1 \mathrm{~g}$ of solid to $80 \mathrm{~mL}$ of alkaline solution was used (Del Campo, et al., 2018). Finally, the material was washed to neutral $\mathrm{pH}$, separated by vacuum filtration and dried at $120{ }^{\circ} \mathrm{C}$ for $12 \mathrm{~h}$ (Z22-HS40-Des sample).

\subsection{Heat treatment and ion-exchange}

All synthesized samples were calcined at $550{ }^{\circ} \mathrm{C}$ for $6 \mathrm{~h}$ in a muffle furnace, at a heating rate of $2{ }^{\circ} \mathrm{C} \mathrm{min}^{-1}$, under an air flow of $100 \mathrm{~mL} \mathrm{~min}{ }^{-1}$. All calcined materials were submitted to three consecutive ion exchange steps with $0.5 \mathrm{~mol} \mathrm{~L}^{-1}$ 
Research, Society and Development, v. 11, n. 3, e6411326070, 2022

(CC BY 4.0) | ISSN 2525-3409 | DOI: http://dx.doi.org/10.33448/rsd-v11i3.26070

ammonium nitrate solution (Sigma-Aldrich, 99\%) at $60{ }^{\circ} \mathrm{C}$ for $2 \mathrm{~h}$, to obtain zeolite in its acidic form. The ratio of $1 \mathrm{~g}$ of solid to $75 \mathrm{~mL}$ of solution was used. After the ion exchanges, the materials were oven dried at $100{ }^{\circ} \mathrm{C}$ for $12 \mathrm{~h}$. Finally, a new heat treatment was carried out, under a synthetic air flow of $100 \mathrm{~mL} \mathrm{~min}{ }^{-1}$ at a heating rate of $2{ }^{\circ} \mathrm{C} \min ^{-1}$ up to $550{ }^{\circ} \mathrm{C}$ for $6 \mathrm{~h}$.

\subsection{Characterization}

The X-ray diffraction analysis (XRD) was performed in a Shimadzu XRD-6000 diffractometer, CuK $\alpha(\lambda=0.1542$ $\mathrm{nm}$ ), Ni filter, $40 \mathrm{kV}$ voltage and $30 \mathrm{~mA}$ current. The data was collected in the $2 \theta$ range between 3 and $40^{\circ}$, with goniometer velocity of $2^{\circ} \mathrm{min}^{-1}$ and step of $0.02^{\circ}$. The area of the diffraction peaks located in the $2 \theta$ regions of $10.9^{\circ}-19.67^{\circ}$ and $23.6^{\circ}-$ $25.0^{\circ}$ (Sousa, et al., 2017) were used to calculate the crystallinity of the materials.

Nitrogen adsorption-desorption measurements were performed using a Micromeritics ASAP 2020 equipment at -196 ${ }^{\circ} \mathrm{C}$, in the relative pressure range $\left(\mathrm{P} / \mathrm{P}_{0}\right)$ between 0.01 and 0.99 . The solids were previously degassed at $350{ }^{\circ} \mathrm{C}$ for $12 \mathrm{~h}$, under vacuum of $2 \mu \mathrm{mHg}$. The specific surface area $\left(\mathrm{S}_{\mathrm{BET}}\right)$ was calculated using the BET method (Brunauer, Emmett \& Teller, 1938). The microporous area $\left(\mathrm{S}_{\text {Micro }}\right)$, external surface area $\left(\mathrm{S}_{\mathrm{Ext}}\right)$ and microporous volume $\left(\mathrm{V}_{\text {Micro }}\right)$ were determined by the $t-$ plot method (Lippens \& De Boer, 1965). The total pore volume $\left(\mathrm{V}_{\text {Total }}\right)$ was measured using the single-point BET method (Dollimore \& Spooner, 1974) at $\mathrm{P} / \mathrm{P}_{0}=0.995$. The mesoporous volume $\left(\mathrm{V}_{\text {Meso }}\right)$ was obtained by the difference between the total pore volume and the micropore volume $\left(\mathrm{V}_{\text {Meso }}=\mathrm{V}_{\text {Total }}-\mathrm{V}_{\text {Micro }}\right)$ (Silva, et al., 2019). The pore size distribution was obtained from the adsorption branch of the isotherm by the BJH method (Barrett, E. P., Joyner, L. G. \& Halenda, 1951).

Temperature-programmed desorption of ammonia ( $\left.\mathrm{NH}_{3}-\mathrm{TPD}\right)$ was conducted in a multipurpose reaction system (SAMP3 model equipment, Termolab - Brazil) equipped with thermal conductivity detector. In these measurements, a sample of approximately $100 \mathrm{mg}$ was submitted to a pretreatment at $400{ }^{\circ} \mathrm{C}$ for $1 \mathrm{~h}$, under helium atmosphere with a flow rate of 30 $\mathrm{mL} \mathrm{min}^{-1}$. Then, the temperature was reduced to $100{ }^{\circ} \mathrm{C}$ and the sample was kept in contact with the ammonia stream at a flow rate of $30 \mathrm{~mL} \mathrm{~min}^{-1}$ for $40 \mathrm{~min}$. The next step of the analysis was the removal of the physisorbed $\mathrm{NH} 3 \mathrm{molecules}$ at $100{ }^{\circ} \mathrm{C}$ for $1 \mathrm{~h}$, under a helium flow rate of $30 \mathrm{~mL} \mathrm{~min}^{-1}$. Finally, the $\mathrm{NH}_{3}$ desorption curves were obtained in the temperature range between 100 and $800{ }^{\circ} \mathrm{C}$, with a heating rate of $10^{\circ} \mathrm{C} \mathrm{min}^{-1}$ and under helium flow rate of $30 \mathrm{~mL} \mathrm{~min}^{-1}$.

Scanning electron microscopy (SEM) was carried out using a Shimadzu SSX-550 and Mira3 Tescan electron microscopes. Thermal analyzes (TG/DTG) were used to determine the coke content of the partially deactivated samples after the n-heptane catalytic cracking reaction, and were carried out in a Shimadzu DTG-60H thermobalance, using alumina crucibles, with sample mass of approximately $6 \mathrm{mg}$. The catalysts were previously treated under a nitrogen atmosphere with a flow rate of $50 \mathrm{~mL} \mathrm{~min}^{-1}$ for $1 \mathrm{~h}$ at $100{ }^{\circ} \mathrm{C}$, to eliminate volatile compounds, and then submitted to a synthetic air atmosphere with a flow rate of $50 \mathrm{~mL} \mathrm{~min}{ }^{-1}$, under a heating rate of $10^{\circ} \mathrm{C} \mathrm{min}-1$ in the range of ambient temperature to $800{ }^{\circ} \mathrm{C}$.

\subsection{Catalytic tests}

The catalytic tests were performed in a Termolab TCAT-3 catalytic evaluation unit. The HZSM-22 samples that, based on the $\mathrm{NH}_{3}$-TPD results, showed higher values of acid site densities were evaluated in the n-heptane cracking model reaction (Sigma-Aldrich, 99\%). The tests were carried out using $100 \mathrm{mg}$ of zeolite in a fixed bed tubular microreactor at 650 ${ }^{\circ} \mathrm{C}$, under atmospheric pressure for $180 \mathrm{~min}$, WHSV of $2 \mathrm{~h}^{-1}$ and nitrogen was used as carrier gas with a flow rate of $20 \mathrm{~mL}$ $\min ^{-1}$. The reaction products were analyzed on a Shimadzu GC-2014 chromatograph equipped with a FID detector. 


\section{Results and Discussion}

\subsection{X-ray diffraction}

Figure 1 shows the X-ray diffractograms of the synthesized samples and the pattern for the TON structure (Treacy \& Higgins, 2007). All samples presented diffraction peaks referring to the ZSM-22 zeolite (JCPDS PDF 38-197), without the presence of impurities compared to the simulated standard diffractogram. The samples crystallinity followed the order: Z22Me-CS $(100 \%)>$ Z22-ADE $(98 \%)>$ Z22-P123 (66\%) > Z22-Vynil (66\%) > Z22-Me (63\%) > Z22-Brij93 (34\%) > Z22$\mathrm{CaCO} 3-\mathrm{HCl}(31 \%)>$ Z22-Starch-Cal $(24 \%)>$ Z22-HS40-Des $(22 \%)$.

Figure 1. X-ray diffractograms of the ZSM-22 samples.
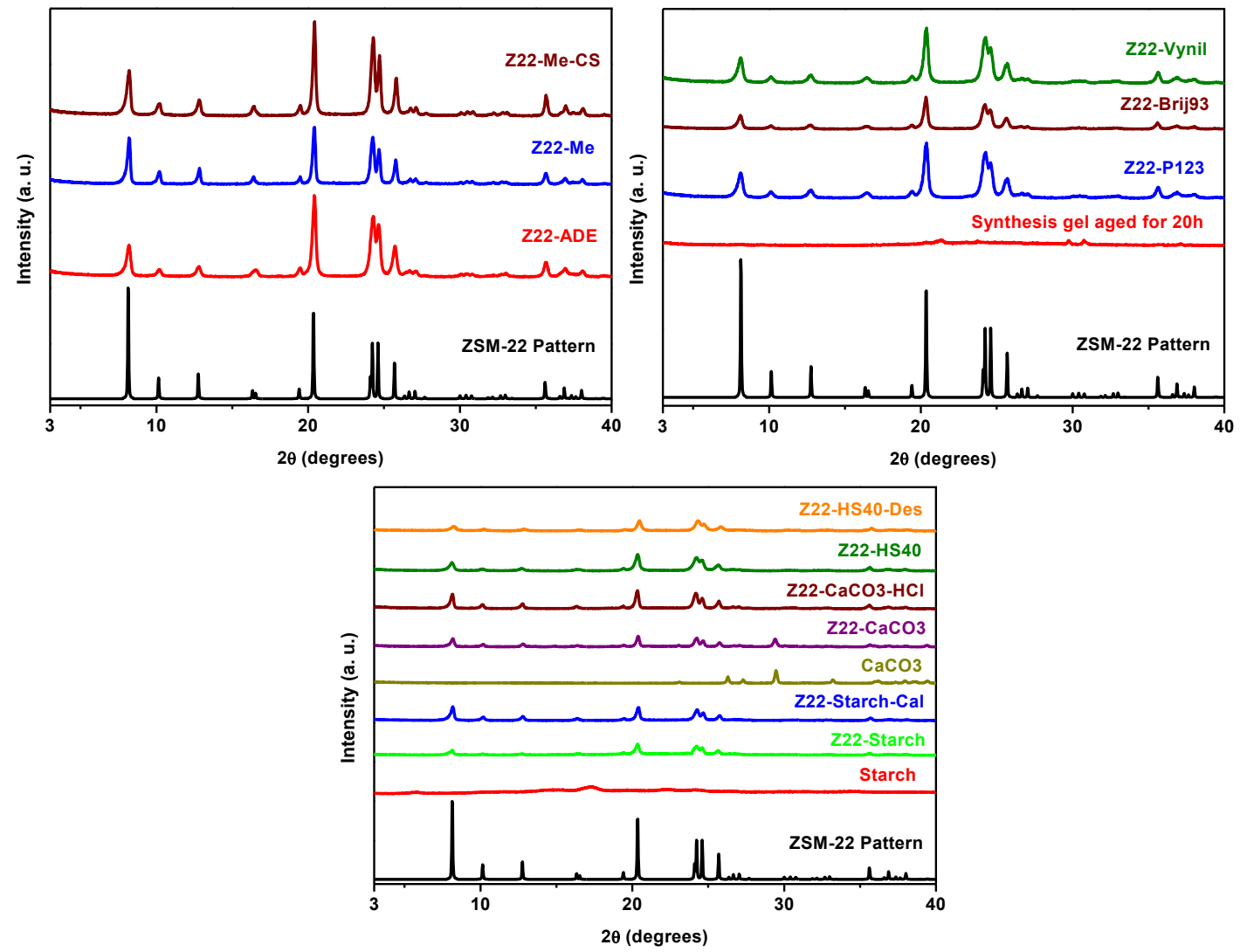

Source: Authors.

The materials synthesized using methanol and seed crystals (Z22-Me-CS) and 1,6-diaminohexane (Z22-ADE) showed diffraction peaks with greater definition and intensity. The use of 1,6-diaminohexane as a structure-directing agent is described in several studies that aimed to obtain ZSM-22, either for structure modification or for application (Liu, et al., 2015; Niu, et al., 2017). The Z22-Me-CS sample obtained the expected result for zeolite synthesis using seed crystals. In this case, it was possible to crystallize ZSM-22 in a short time $(3 \mathrm{~h})$ in the absence of structure-directing agents. Wang et al. (2014) and Sousa et al. (2017) reported a similar effect on the use of seed crystals in the reaction mixture, which act as pre-formed nuclei, thus reducing the crystallization time. The Z22-Me sample showed intermediate crystallinity, which is probably associated with the weak affinity of the $\mathrm{OH}$ group of the alcohol with the zeolitic structure, compared to other organic compounds such as amines (Qian, et al., 2001), resulting in a lesser effect of pore filling and structure directing. Jamil et al. (2016) described the importance of alcohol as a co-solvent, being responsible for promoting the control of crystal growth and inhibiting the 
formation of competing phases.

There is a small crystalline organization along the amorphous phase in the synthesis gel aged for $20 \mathrm{~h}$, which can be attributed to some intermediate species of silicate (Mintova \& Valtchev, 2002). Jamil et al. (2014) reported an increase in the crystallinity of ZSM-22 from $52 \%$ to $98 \%$ with the addition of a small amount of the brij76 surfactant $(\mathrm{Brij} / \mathrm{Al}=2.5)$. However, when adding a greater amount of surfactant (Brij/Al = 10) there was a decrease in crystallinity or amorphous material was formed. Although the amount adopted in this work was Brij/Al $=2.5$, the crystallinity of the material synthesized with Brij93 may be related to the higher molecular weight of this compound (Brij76 MW $=314.6 \mathrm{~g} \mathrm{~mol}^{-1}$ and Brij93 $\mathrm{MW}^{2}$ $356.58 \mathrm{~g} \mathrm{~mol}^{-1}$ ) resulting in an excess amount in the medium reaction, and in this way, slowing down the formation of the ZSM-22 zeolite. According to Aguado, Serrano \& Rodríguez (2008), the presence of the silane group in the reaction mixture would have the function of inhibiting the growth and agglomeration of the zeolite crystals. The same effect observed for the material obtained with Brij93 occurred in the cases of samples synthesized with pluronic P123 and vinyltrimethoxysilane.

The material synthesized using starch (JCPDS PDF 39-1911) showed an amorphous region due to the presence of this compound in the sample. After the calcination process, the ZSM-22 phase became better defined (Z22-Starch-Cal), suggesting the effective removal of starch from the zeolite structure. The sample synthesized with carbonate exhibited a mixture of the ZSM-22 and $\mathrm{CaCO}_{3}$ phases (JCPDS PDF 47-1743). The carbonate was removed after the acid treatment and the characteristic peaks of the TON phase $(\mathrm{Z} 22-\mathrm{CaCO} 3-\mathrm{HCl})$ were the only observed. Both treatments to remove starch and $\mathrm{CaCO}_{3}$ led to an increase in the crystallinity of the zeolites (Starch from $18 \%$ to $24 \%$ and CaCO3 from $18 \%$ to $31 \%$ ). The material obtained with the addition of silanized silica denoted the formation of pure ZSM-22, with a decrease in the intensity of the peaks after desilication (Z22-HS40-Des), due to the extraction of structural silicon atoms (Silva, et al., 2018).

\subsection{Nitrogen adsorption-desorption measurements}

Figure 2 shows the nitrogen adsorption-desorption isotherms of the ZSM-22 zeolites. Practically all samples presented isotherms with a type I profile, exhibiting low adsorbed amounts in the range of $\mathrm{P} / \mathrm{P}_{0}<0.1$, related to the typical microporosity of the TON structure (He, et al., 2021), with a small increase in adsorption in the range $\mathrm{P} / \mathrm{P}_{0}<0.8$, indicative of the intercrystalline voids of nanorod clusters. The exception was the Z22-Me-CS sample, which showed a combination of isotherms with types I and IV profiles, with the formation of a hysteresis at relative pressures between $0.6<\mathrm{P} / \mathrm{P}_{0}<1.0$, denoting a micro-mesoporous material. The BJH distribution exhibits an "apparent" mesoporosity for the samples Z-ADE, Z22-Me-CS and Z22-Brij93, possibly due to the filling of irregular pores formed by the intergrowth between the crystals or particles that form these materials (Carvalho \& Urquieta-Gonzalez, 2015). Z22-HS40-Des and Z22-Starch-Cal samples had pores distribution in the micro-mesopore range, which is effect of the post-synthesis treatment carried out on the solids.

The textural properties obtained from the nitrogen adsorption-desorption analyzes are listed in Table 1. The results for the Z22-ADE sample are similar to the values described in the literature (Lazareva, et al., 2019), indicating the effectiveness of 1,6-diaminohexane as OSDA to synthesize the TON structure. The Z22-Me sample had lower area and volume values, denoting a lower "filling" effect of the zeolite pores by methanol in relation to the amine. The use of crystallization seeds (Z22-Me-CS) provided an increase in the external area and, together with the Z22-ADE sample, resulted in a pseudo mesoporosity, due to the interstices between the nanorod clusters (Sousa, et al., 2017). The materials prepared with the aging of the synthesis gel and subsequent polymer surfactant and silane addition (Z22-P123, Z22-Brij93 and Z22-Vynil) showed an increase in the external area in comparison to Z22-ADE sample, as they are formed by smaller crystals (Jamil, et al.; 2014). The sample obtained with silanized and desilicate silica (Z22-HS40-Des) effectively showed an increase in $\mathrm{S}_{\text {Ext }}$ and generation of $\mathrm{V}_{\text {Meso }}$, as described in the BJH distribution. 
Figure 2. Nitrogen adsorption-desorption isotherms of ZSM-22 samples. For better visualization, the following isotherms were shifted: Z22-20h-Brij93 $\left(40 \mathrm{~cm}^{3} \mathrm{~g}^{-1}\right)$ and Z22-Vynil $\left(130 \mathrm{~cm}^{3} \mathrm{~g}^{-1}\right)$.
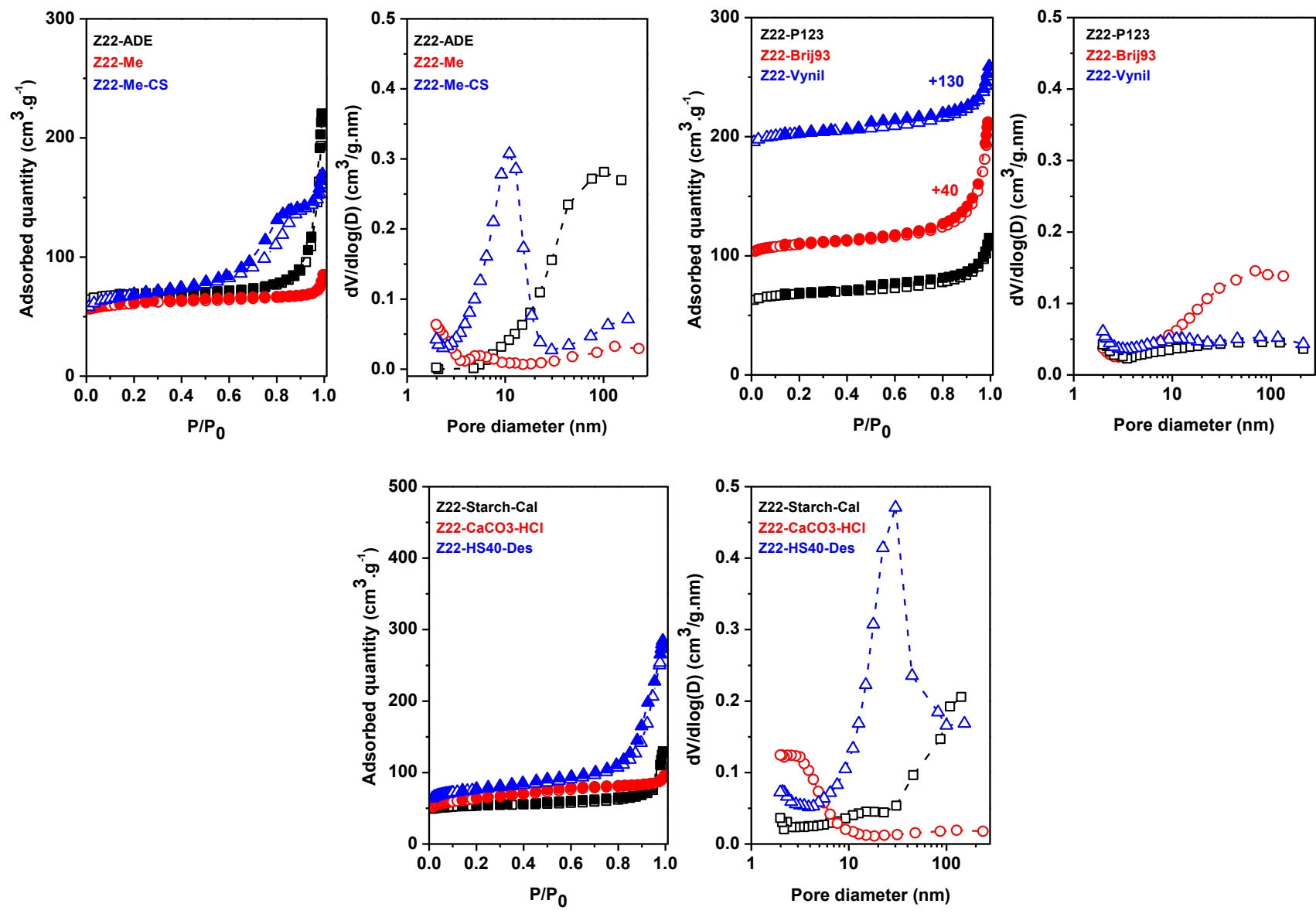

Source: Authors.

Table 1. Textural properties obtained from nitrogen adsorption-desorption analyses.

\begin{tabular}{ccccccc}
\hline Sample & $\begin{array}{c}\text { SBET } \\
\left(\mathbf{m}^{\mathbf{2}} \mathbf{g}^{-\mathbf{1}}\right)\end{array}$ & $\begin{array}{c}\text { SMicro } \\
\left(\mathbf{m}^{\mathbf{2}} \mathbf{g}^{-\mathbf{1}}\right)\end{array}$ & $\begin{array}{c}\text { SExt } \\
\left(\mathbf{m}^{\mathbf{2}} \mathbf{g}^{-\mathbf{1}}\right)\end{array}$ & $\begin{array}{c}\text { VTotal } \\
\left(\mathbf{c m}^{\mathbf{3}} \mathbf{g}^{-\mathbf{1}}\right)\end{array}$ & $\begin{array}{c}\text { VMicro } \\
\left(\mathbf{c m}^{\mathbf{3}} \mathbf{g}^{\mathbf{- 1}}\right)\end{array}$ & $\begin{array}{c}\text { VMeso } \\
\left(\mathbf{c m}^{\mathbf{3}} \mathbf{g}^{-\mathbf{1}}\right)\end{array}$ \\
\hline Z22-ADE & 265 & 243 & 20 & 0.23 & 0.1 & 0.13 \\
Z22-Me & 229 & 198 & 31 & 0.11 & 0.08 & 0.03 \\
Z22-Me-CS & 254 & 185 & 71 & 0.23 & 0.08 & 0.16 \\
Z22-P123 & 259 & 224 & 35 & 0.15 & 0.09 & 0.06 \\
Z22-Brij93 & 263 & 223 & 40 & 0.20 & 0.09 & 0.11 \\
Z22-Vynil & 276 & 230 & 46 & 0.17 & 0.09 & 0.08 \\
Z22-Starch-Cal & 162 & 129 & 33 & 0.13 & 0.05 & 0.08 \\
Z22-CaCO3-HCl & 202 & 175 & 27 & 0.14 & 0.07 & 0.07 \\
Z22-HS40-Des & 282 & 192 & 90 & 0.39 & 0.08 & 0.31
\end{tabular}

Source: Authors. 
Research, Society and Development, v. 11, n. 3, e6411326070, 2022

(CC BY 4.0) | ISSN 2525-3409 | DOI: http://dx.doi.org/10.33448/rsd-v11i3.26070

\subsection{Scanning electron microscopy}

The micrographs (Figure 3) in general did not show differences in the morphology of the materials, that are composed of agglomerates of crystals with nanorods shape, characteristic of ZSM-22 (Li, et al., 2021), with size in the 1-2 $\mu$ m range. The interstices between the crystals provided the characteristic of a pseudo mesoporosity, for purely microporous materials, obtained from nitrogen adsorption-desorption analyses. The exception was the Z22-Vynil sample, which exhibited crystals with a higher agglomeration degree, taking the form of practically a single particle. Due to the peculiar morphology of the ZSM-22, it was not observed cracks in the crystals of the Z22-HS40-Des sample caused by the desilication process, as reported by Verboekend et al. (2011). The effect of micro-mesoporosity generation was better highlighted by the nitrogen adsorptiondesorption analyses.

Figure 3. Micrographs of the ZSM-22 samples: (a) Z22-ADE, (b) Z22-Me, (c) Z22-Me-CS, (d) Z22-P123, (e) Z22-Brij93, (f) ) Z22-Vynil, (g) Z22-HS40-Des, (h) Z22-CaCO3-HCl and (i) Z22-Starch-Cal.
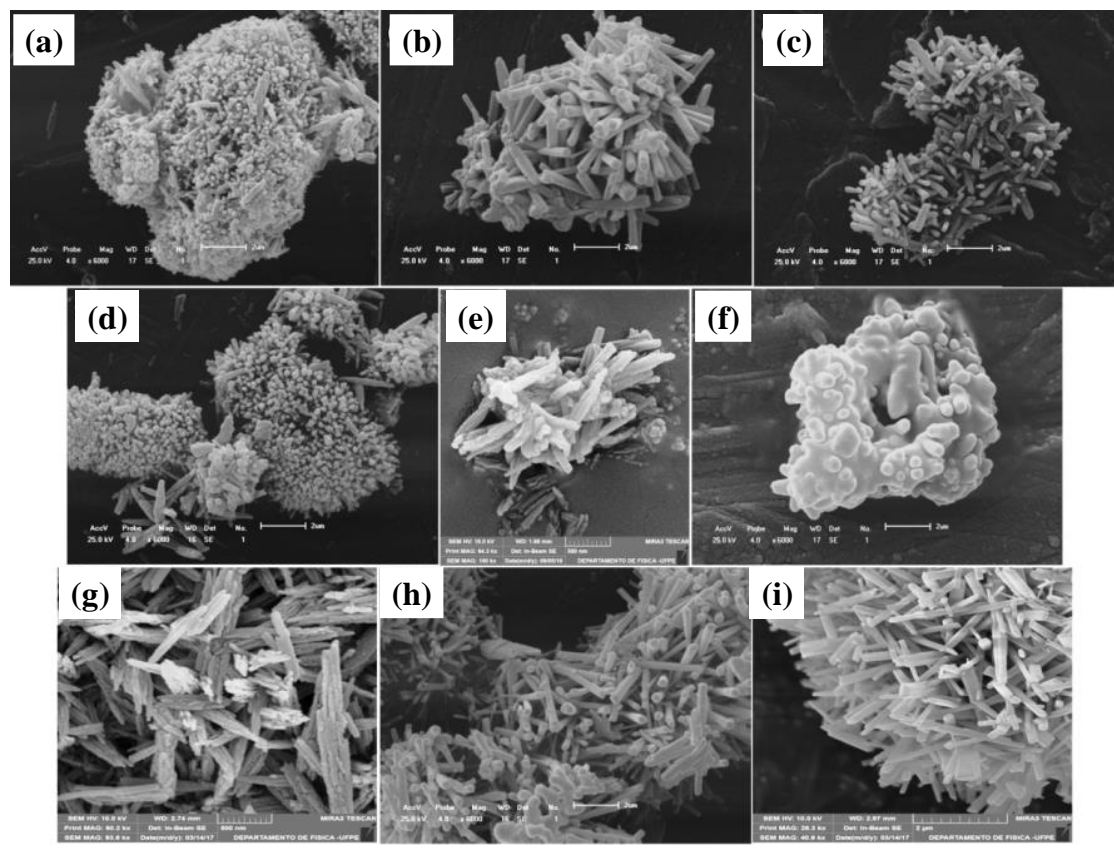

Source: Authors.

\subsection{Temperature-programmed desorption of ammonia}

Figure 4 shows the ammonia desorption profiles of the ZSM-22 zeolites. All samples provided two main peaks of ammonia desorption, one approximately between 100 and $320^{\circ} \mathrm{C}$ and the other in the range of 320 and $550{ }^{\circ} \mathrm{C}$, indicating the presence of Lewis and Brønsted acidity, respectively (Li, et al., 2017; Silva, et al., 2020). The first low temperature desorption event represents the weak acidic sites and the second high temperature event is attributed to the strong acidity sites (Gao, et al., 2020; Quintela, et al., 2021). The exceptions were the Z22-Vynil and Z22-CaCO3-HCl samples, which exhibited a third less intense peak between 550 and $620^{\circ} \mathrm{C}$. This fact is linked to a process of dehydroxylation of the structures (Lok, Marcus $\&$ Angell, 1986). 
Figure 4. $\mathrm{NH}_{3}$-TPD profiles of ZSM-22 samples.
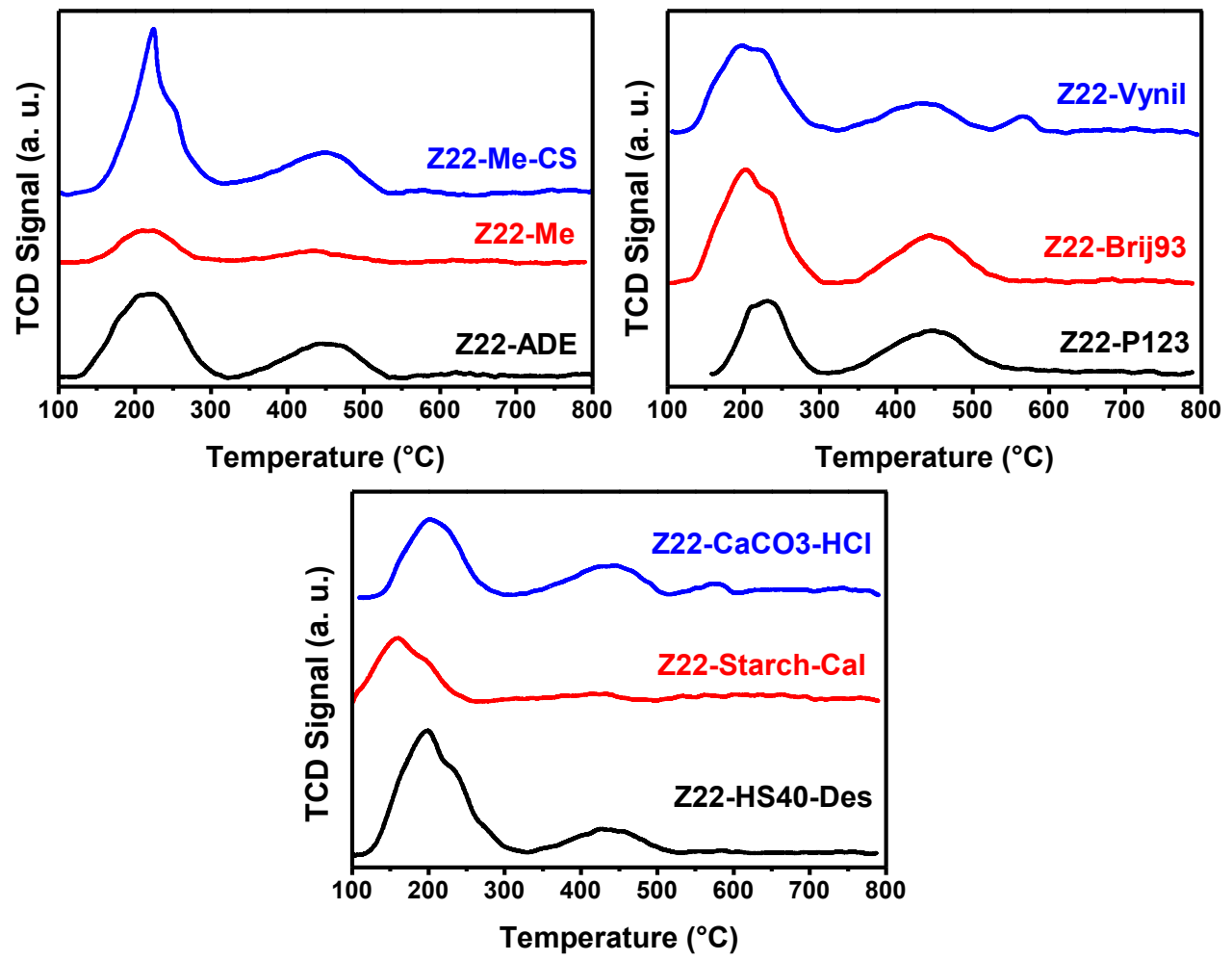

Source: Authors.

Assuming the stoichiometry of one ammonia molecule per acid site, the acid site densities can be obtained from the Gaussian deconvolution of the TPD curves (Lok, et al., 1986). The results from the $\mathrm{NH}_{3}$-TPD analyzes are listed in Table 2. Nearly all synthesized samples had higher densities of weak acidic sites compared to strong acidic sites, which is a negative effect, since Brønsted acidity plays a role of greater importance in the catalytic cracking of hydrocarbons (Gao, et al., 2020). The exception was the Z22-P123 sample, which showed similar densities between the two desorption events.

Hayasaka et al. (2007) reported that through X-ray excited photoelectron spectroscopy (XPS) analysis they observed that a large part of the aluminum was located on the external surface of the ZSM-22 crystals, having a very siliceous internal structure. Recent investigations on aluminum location in TON type zeolites by NMR techniques revealed a preferential population of T3 and T4 sites (Camblor et al.,1998). Especially the T4 sites located in lobes of the main because they are prime candidates for aluminum positions (Hayasaka, et al., 2007). This implies a higher proportion of acid sites near pore mouths (Thaker, et al., 2016), which favour undesirable bimolecular reactions, such as alkylation, hydrogen transfer and isomerization, because of less spatial restrictions (Rahimi \& Karimzadeh, 2011). Primary products (such as ethylene and propene) can undergo further reactions at external acid sites, leading to the formation of coke precursors (benzene, toluene and xylenes) and coke deposits (Javaid, et al., 2015; Inagaki, et al., 2016).

The samples that were submitted to a post-synthesis treatment, Z22-HS40-Des and Z22-CaCO3-HCl, possibly suffered a certain degree of structure dealuminization. Verboekend et al. (2011) reported that due to the peculiar morphology of the ZSM-22 crystals in the form of "needles" and the higher concentration of Al on the external surface, alkaline and/or acid treatments, despite generating inter- and intra-crystal mesoporosity, can lead to the leaching of part of the aluminum atoms of the zeolitic structure and even the breakdown of the finest crystals, which can influence the catalytic properties of these materials. 
Research, Society and Development, v. 11, n. 3, e6411326070, 2022

(CC BY 4.0) | ISSN 2525-3409 | DOI: http://dx.doi.org/10.33448/rsd-v11i3.26070

Table 2. Results obtained from the $\mathrm{NH}_{3}-\mathrm{TPD}$ analyses.

\begin{tabular}{|c|c|c|c|c|c|}
\hline \multirow[b]{2}{*}{ Sample } & \multicolumn{2}{|c|}{ 1st Peak } & \multicolumn{2}{|c|}{ 2nd Peak } & \multirow{2}{*}{$\begin{array}{c}\sum \mathrm{C} \\
\left(\mu \mathrm{mol} \mathrm{g} \mathbf{g}^{-1}\right)\end{array}$} \\
\hline & $\begin{array}{l}\mathbf{T}_{\text {Max }} \\
\left({ }^{\circ} \mathbf{C}\right)\end{array}$ & $\begin{array}{c}\mathrm{C} \\
\left(\mu \mathrm{mol} \mathrm{g} \mathrm{g}^{-1}\right)\end{array}$ & $\begin{array}{l}\mathbf{T}_{\text {Max }} \\
\left({ }^{\circ} \mathbf{C}\right)\end{array}$ & $\begin{array}{c}\mathrm{C} \\
\left.(\mu \mathrm{mol} \mathrm{g})^{-1}\right)\end{array}$ & \\
\hline Z22-ADE & 224 & 264 & 457 & 119 & 383 \\
\hline Z22-Me & 217 & 102 & 436 & 40 & 142 \\
\hline Z22-Me-CS & 224 & 291 & 454 & 125 & 416 \\
\hline Z22-P123 & 233 & 121 & 449 & 123 & 244 \\
\hline Z22- Brij93 & 204 & 244 & 448 & 117 & 360 \\
\hline Z22-Vynil & 198 & 197 & 437 & 66 & 263 \\
\hline Z22-HS40-Des & 203 & 265 & 443 & 56 & 321 \\
\hline $\mathrm{Z} 22-\mathrm{CaCO} 3-\mathrm{HCl}$ & 161 & 150 & 444 & 73 & 223 \\
\hline Z22-Starch-Cal & 202 & 121 & 576 & 17 & 138 \\
\hline
\end{tabular}

Source: Authors.

\subsection{Catalytic performance}

From the textural properties and total density of acidic sites results, the Z22-ADE, Z22-Me-CS, Z22-Brij93 and Z22HS40-Des samples were selected to evaluate the catalytic performance in the n-heptane cracking reaction.

The conversions and coke content of ZSM-22 zeolites for the catalytic cracking of n-heptane are shown in Figure 5. It was found that the Z22-ADE and Z22-Brij93 samples showed higher initial conversions, followed by a strong decrease in catalytic activity. This led to a higher coke content deposited on these microporous materials. The Z22-Me-CS and Z22-HS40Des samples initially provided lower conversions, showing greater stability during the reaction time. The Z22-Me-CS sample, despite having strong acid site density similar to Z22-ADE and Z22-Brij93, does not exhibited the same catalytic activity behavior, indicating that for these one-dimensional materials the acidity is related not only to the $\mathrm{SiO}_{2} / \mathrm{Al}_{2} \mathrm{O}_{3}$ ratio, but also with the coordination of aluminum atoms in the crystal structure (Silva, et al., 2019). The lower activity showed by the Z22HS40 sample is related to a lower density of strong acid sites, resulting from a certain degree of dealuminization of the structure after desilication (Verboekend, et al., 2011). On the other hand, the generation of mesopores led to a greater stability and lower coke content compared to the microporous zeolites. 
Figure 5. (a) Conversion and (b) coke content of ZSM-22 samples in n-heptane catalytic cracking reaction.
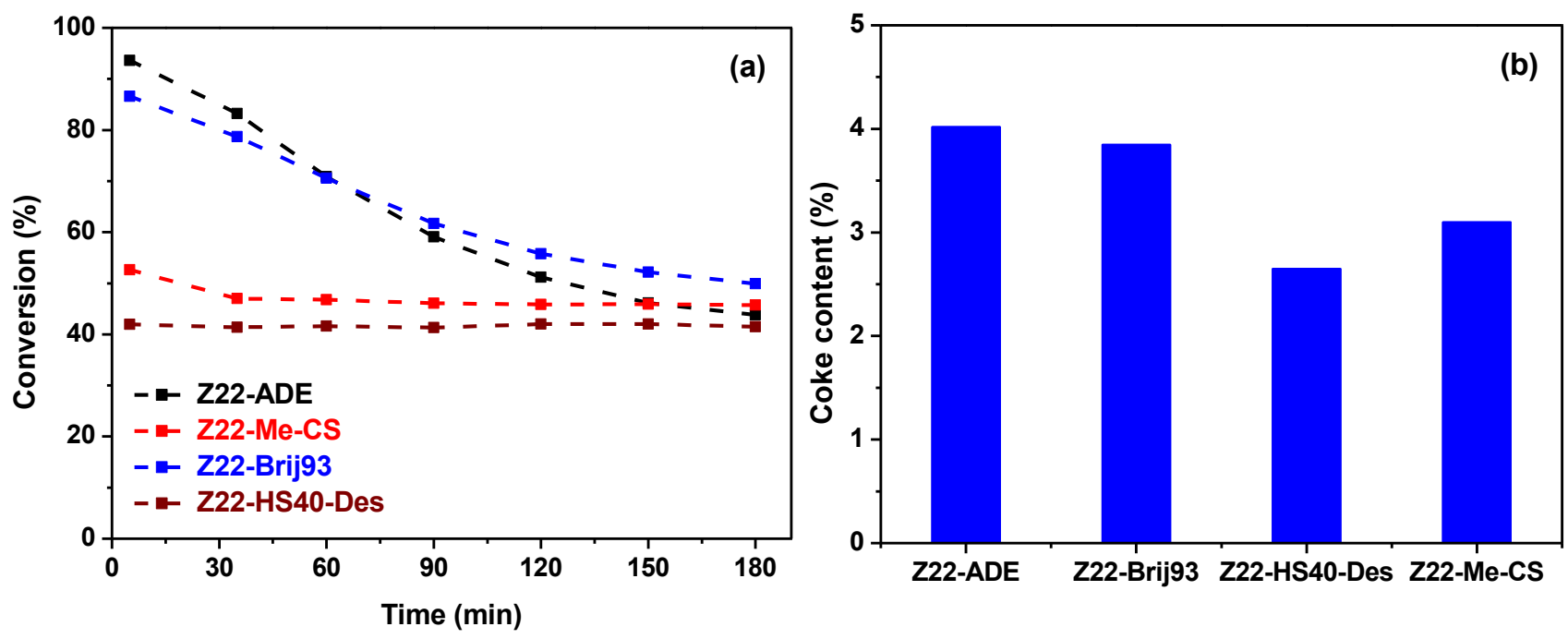

Source: Authors.

The coke content was measured by thermal analysis (Figure 6), where it was found that all catalysts had two mass loss events, with the first occurring at temperatures below $550{ }^{\circ} \mathrm{C}$, due to thermal degradation of light coke (aliphatic compounds), and the second at temperatures above $550{ }^{\circ} \mathrm{C}$, attributed to the combustion of heavy coke (aromatic compounds) (Zhang, et al., 2018). The deactivation process of zeolites occurs mainly due to the formation of coke, which is produced through secondary reactions that occur on the catalyst surface, which can lead to the blocking of pore openings and deactivation of active sites. Therefore, the mesopores generated in the Z22-HS40-Des sample allowed an increase in molecular diffusion, and with this, the micropores were more slowly blocked due to the greater accessibility to the interior of the zeolite structure (Silva, et al., 2022).

Figure 6. TG/DTG curves of ZSM-22 samples after n-heptane catalytic cracking reaction: (a) Z22-ADE, (b) Z22-MeCS, (c) Z22-Brij93 and (d) Z22-HS40-Des.
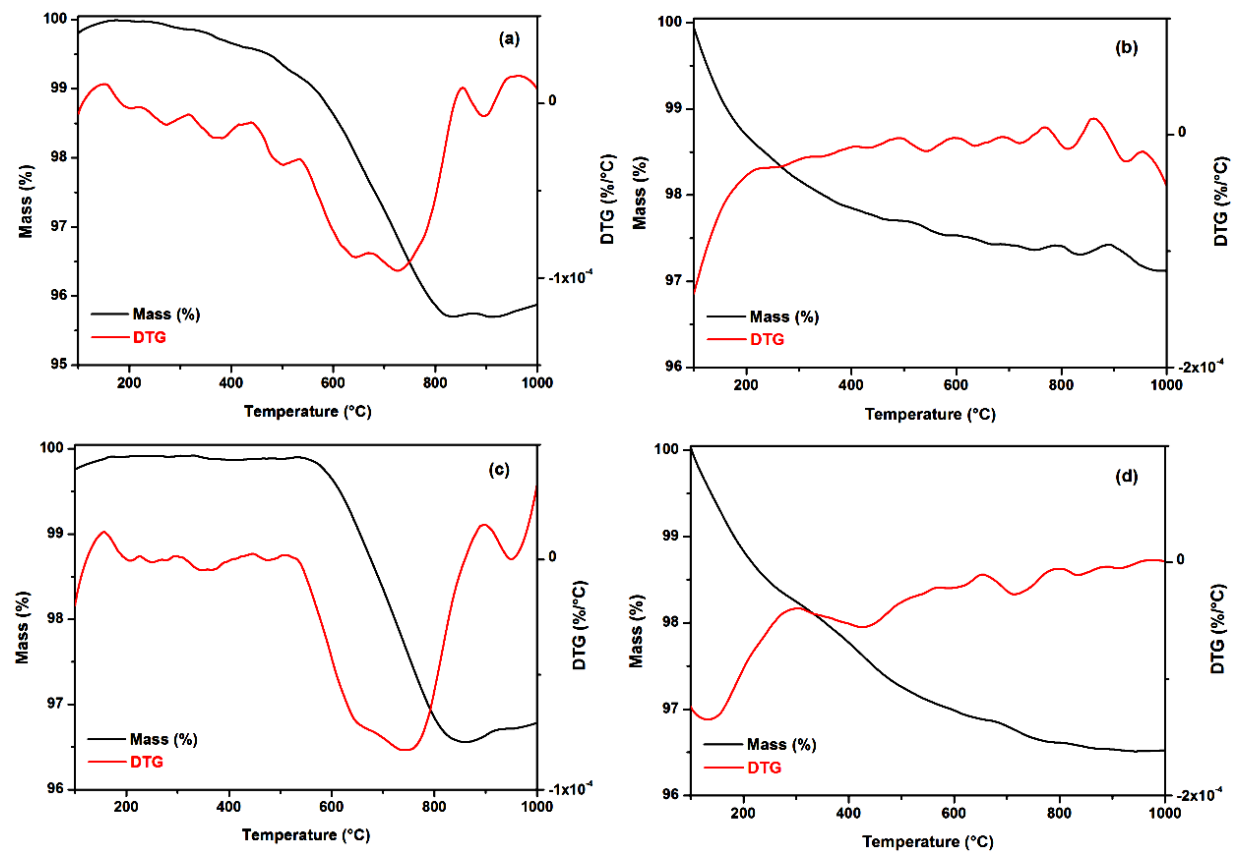

Source: Authors. 
The products distribution obtained in the n-heptane catalytic cracking is listed in Table 3 . There was no significant change in the products percentage, in which all catalysts showed selectivity to the formation of compounds in the range $\mathrm{C} 2$ to C4 in similar proportions. The reaction temperature used favors the formation of ethene, as it is formed by primary carbonium ions that require high activation energy (Wang, et al., 2015).

Table 3. N-heptane catalytic cracking products distribution and coke content after 180 min of reaction.

\begin{tabular}{cccccc}
\hline \multirow{2}{*}{ Sample } & \multicolumn{5}{c}{ Product distribution (\%) } \\
\cline { 2 - 6 } & $\mathbf{C}_{\mathbf{1}}$ & $\mathbf{C}_{\mathbf{2}}$ & $\mathbf{C}_{\mathbf{3}}$ & $\mathbf{C}_{\mathbf{4}}$ & $\mathbf{C}_{5+}$ \\
\hline Z22-ADE & 1.0 & 10.0 & 32.0 & 32.0 & 25.0 \\
Z22-Me-CS & 1.0 & 12.0 & 33.0 & 30.0 & 24.0 \\
Z22-Brij93 & 1.0 & 13.0 & 40.0 & 36.0 & 11.0 \\
Z22-HS40-Des & 1.0 & 11.0 & 34.0 & 33.0 & 21.0 \\
\hline
\end{tabular}

Source: Authors.

\section{Conclusion}

ZSM-22 zeolite was successfully obtained from all the studied synthesis routes. The use of methanol together with seed crystals led to a reduction in crystallization time $(3 \mathrm{~h})$, with the Z22-Me-CS sample being the most crystalline (100\%). The acidity, specific area and volume values were close to those obtained from conventional synthesis (Z22-ADE) that uses 1,6-diaminohexane as an organic structure-directing agent. The synthesis using only methanol (Z22-Me) resulted in the crystallization of ZSM-22 with inferior characteristics in comparison to Z22-ADE, indicating a low interaction of alcohol with the zeolitic structure. The aging of the synthesis gel with subsequent addition of polymer, surfactant and silane did not cause significant changes in the properties of ZSM-22. Among the synthesis routes using calcium carbonate, starch and silanized silica followed by alkaline post-treatment, only the latter generated the micro-mesoporous ZSM-22.

The optimization of the ZSM-22 synthesis is not easy to perform, because, as reported in the literature, this zeolite has a formation process sensitive to any slight change in the synthesis parameters, which may lead to undesired physicochemical characteristics or even contamination by other crystalline phases. For further research, we propose the study of the synthesis of ZSM-22 with the simultaneous use of different amines, to evaluate the effect of different kinetic diameters and affinity of these compounds on the crystallization, textural properties and acid density of the zeolite. Another proposed study is the application of amino acids salts as possible mesoporosity agents, in order to obtain micro-mesoporous structures to improve the diffusivity in the ZSM-22 zeolite.

\section{Acknowledgments}

The authors are grateful for the financial support of the Coordenação de Aperfeiçoamento de Pessoal de Nível Superior (CAPES), through a research grant and the Petrobras.

\section{References}

Afroukhteh-Langaroudi, N.; Tarighi, S., \& Khonakdara, H. A. (2018). Catalytic Cracking of n-Hexane and n-Heptane over ZSM-5 Zeolite: Influence of $\mathrm{SiO}_{2} / \mathrm{Al}_{2} \mathrm{O}_{3}$ Ratio. Petroleum Chemistry, 58, 457-463.doi:10.1134/S096554411805002X

Barrett, E. P., Joyner, L. G., \& Halenda, P. P. (1951). The Determination of Pore Volume and Area Distributions in Porous Substances. I. Computations from Nitrogen Isotherms. Journal of the American Chemical Society, 73(1), 373-380.doi:10.1021/ja01145a126 
Research, Society and Development, v. 11, n. 3, e6411326070, 2022

(CC BY 4.0) | ISSN 2525-3409 | DOI: http://dx.doi.org/10.33448/rsd-v11i3.26070

Blay, V.; Louis, B.; Miravalles, R.; Yokoi, T.; Peccatiello, K. A.; Clough, M., \& Yilmaz, B. (2017). Engineering zeolites for catalytic cracking to light olefins. ACS Catalysis, 7, 6542-6566.doi:10.1021/acscatal.7b02011

Brunauer, S.; Emmett, P. H., \& Teller, E. (1938). Adsorption of Gases in Multimolecular Layers. Journal of the American Chemical Society, 60(2), 309-319. doi:10.1021/ja01269a 023

Camblor, M. A.; Corma, A., \& Valencia, S. (1998). Characterization of nanocrystalline zeolite Beta. Microporous and Mesoporous Materials, $25,59-74$. doi:10.1016/S1387-1811(98)00172-3.

Chen, Z.; Liu, S.; Wang, H.; Ning, Q.; Zhang, H.; Yun, Y.; Ren, J., \& Li, Y.-W. (2018). Synthesis and characterization of bundle-shaped ZSM-22 zeolite via the oriented fusion of nanorods and its enhanced isomerization performance. Journal of Catalysis, 361, 177-185.doi:10.1016/j.jcat.2018.02.019

Corma, A.; Melo, F. V.; Sauvanaud, L., \& Ortega, F. (2005). Light cracked naphtha processing: Controlling chemistry for maximum propylene production. Catalysis Today, 107-108, 699-706.doi:10.1016/j.cattod.2005.07.109

Corma, A.; Corresa, E.; Mathieu, Y.; Sauvanaud, L.; Al-Bogami, S.; Alghrami, M. S., \& Bourane, A. (2017). Crude oil to chemicals: Light olefins from crude oil. Catalysis Science \& Technology, 7, 12-46.doi:10.1039/C6CY01886F

Dagle, V. L.; Lopez, J. S.; Cooper, A.; Luecke, J.; Swita, M.; Dagle, R. A., \& Gaspar, D. (2020). Production and fuel properties of iso-olefins with controlled molecular structure and obtained from butene oligomerization. Fuel, 277, 118147.doi:10.1016/j.fuel.2020.118147

Del Campo, P.; Beato, P.; Rey, F.; Navarro, M. T.; Olsbye, U.; Lillerud, K. P., \& Svelle, S. (2018). Influence of post-synthetic modifications on the composition, acidity and textural properties of ZSM-22 zeolite. Catalysis Today, 299, 120-134.doi:10.1016/j.cattod.2017.04.042

Del Campo, P.; Olsbye, U.; Lillerud, K. P.; Svelle, S., \& Beato, P. (2018). Impact of post-synthetic treatments on unidirectional H-ZSM-22 zeolite catalyst: Towards improved clean MTG catalytic process. Catalysis Today, 299, 135-145.doi:10.1016/j.cattod.2017.05.011

Dollimore, D., \& Spooner, P. (1974). A Single Point Method for Evaluating the Specific Surface Area of a Solid from Nitrogen Adsorption Isotherms. Journal of Chemical Technology \& Biotechnology, 24, 35-41.doi:10.1002/jctb.2720240104

Dyballa, M.; Obenaus, U.; Rosenberger, M.; Fischer, A.; Jakob, H.; Klemm, E., \& Hunger, M. (2016). Post-synthetic improvement of H-ZSM-22 zeolites for the methanol-to-olefin conversion. Microporous and Mesoporous Materials, 233, 26-30.doi:10.1016/j.micromeso.2016.06.044

Gao, S.-B.; Zhao, Z.; Lu, X.-F.; Chi, K.-B.; Duan, A.-J.; Liu, Y.-F.; Meng, X.-B.; Tan, M.-W.; Yu, H.-Y.; Shen, Y.-G., \& Li, M.-C. (2020). Hydrocracking diversity in n-dodecane isomerization on Pt/ZSM-22 and Pt/ZSM-23 catalysts and their catalytic performance for hydrodewaxing of lube base oil. Petroleum Science, 17, 1752-1763.doi:10.1007/s12182-020-00500-7

Gollakota, A. R. K.; Volli, V.; Munagapati, V. S.; Wen, J.-C. \& Shu, C.-M. (2020). Synthesis of novel ZSM-22 zeolite from Taiwanese coal fly ash for the selective separation of Rhodamine 6G. Journal of Materials Research and Technology, 9, 15381-15393.doi:10.1016/j.jmrt.2020.10.070

Hayasaka, K.; Liang, D.; Huybrechts, W.; De Waele, B. R.; Houthoofd, P. E.; Gaigneaux, E. M. van Tendeloo, G.; Thybaut, J. W.; Marin, G. B.; Denayer, J. F. ; Baron, G. V.; Jacobs, P. A.; Kirschhock, C. E. A., \& Martens, J. A. (2007). Formation of ZSM-22 Zeolite Catalytic Particles by Fusion of Elementary Nanorods. Chemistry-A European Journal, 13, 10070-10077.doi:10.1002/chem.200700967.

He, L.. Fu, W.; Li, L.; Huang, Y.; Chen, L.; Wu, D.; Zhang, L., \& Tang, T. (2021). Study of CA-treated ZSM-22 zeolite with enhanced catalytic performance in the hydroisomerization of long-chain n-dodecane. New Journal of Chemistry, 45, 2820-2829.

doi:10.1039/D0NJ05190J

Inagaki, S.; Shinoda, S.; Hayashi, S.; Wakihara, T.; Yamazaki, H.; Kondo, J. N., \& Kubota, Y. (2016). Improvement in the catalytic properties of ZSM-5 zeolite nanoparticles via mechanochemical and chemical modifications. Catalysis Science \& Technology, 6, 2598-604.doi:10.1039/C5CY01644D.

Jamil, A. K.; Muraza, O.; Sanhoob, M.; Tago, T.; Konno, H.; Nakasaka, Y., \& Masuda, T. (2014). Controlling naphtha cracking using nanosized TON zeolite synthesized in the presence of polyoxyethylene surfactant. Journal of Analytical and Applied Pyrolysis, 110, 338-345.doi:10.1016/j.jaap.2014.09.023

Jamil, A. K.; Muraza, O., \& Al-Amer, A. M. (2015). The role of alcohols and diols as co-solvents in fabrication of TON zeolite. Journal of Industrial and Engineering Chemistry, 29, 112-119.doi:10.1016/j.jiec.2015.03.023

Jamil, A. K.; Muraza, O., \& Al-Amer, A. M. (2016). Microwave-assisted solvothermal synthesis of ZSM-22 zeolite with controllable crystal lengths. Particuology, 24, 138-141.doi:10.1016/j.partic.2015.09.002

Javaid, R.; Urata, K.; Furukawa, S., \& Komatsu, T. (2015). Factors affecting coke formation on H-ZSM-5 in naphtha cracking. Applied Catalysis A: General, 491, 100-105.doi:10.1016/j.apcata.2014.12.002.

Li, S.; Li, J.; Dong, M.; Fan, S.; Zhao, T.; Wang, J., \& Fan, W. (2019). Strategies to control zeolite particle morphology. Chemical Society Reviews, 48, 885907.doi:10.1039/C8CS00774H

Lippens, B. C., \& De Boer, J. H. (1965). Studies on pore systems in catalysts: V. The t method. Journal of Catalysis, 4(3), 319-323.doi:10.1016/00219517(65)90307-6

Liu, S.; Ren, J.; Zhu, S.; Zhang, H.; Lv, E.; Xu, J., \& Li, Y.-W. (2015). Synthesis and characterization of the Fe-substituted ZSM-22 zeolite catalyst with high n-dodecane isomerization performance. Journal of Catalysis, 330, 485-496.doi:10.1016/j.jcat.2015.07.027 
Research, Society and Development, v. 11, n. 3, e6411326070, 2022

(CC BY 4.0) | ISSN 2525-3409 | DOI: http://dx.doi.org/10.33448/rsd-v11i3.26070

Liu, Z.; Chu, Y.; Tang, X.; Huang, L.; Li, G.; Yi, X., \& Zheng, A. (2017). Diffusion Dependence of the Dual-Cycle Mechanism for MTO Reaction Inside ZSM-12 and ZSM-22 Zeolites. Journal of Physical Chemistry C, 121, 22872-22882.doi:10.1021/acs.jpcc.7b07374

Li, Y.-S.; Wen, Z.-H.; Wei, Z.-H.; Yang, F., \& Zhu, X.-D. (2017). Catalytic study for the alkylation of benzene with methanol over ZSM-22 and ZSM-35. Catalyst Research, 19(4), 38-46. http://www.chinarefining.com/EN/Y2017/V19/I4/38

Li, X.; Tsai, S.-T.; Wu, K. C.-W.; Curnow, O. J.; Choi, J. \& Yip, A. C. K. (2021). Morphology control of ionic-liquid-templated ZSM-22 and ZSM-5 zeolites using a two-step process and its effect on toluene methylation. Microporous and Mesoporous Materials, 328, 111475.doi:10.1016/j.micromeso.2021.111475.

Lok, B. M.; Marcus, B. K., \& Angell, C. L. (1986). Characterization of zeolite acidity. II. Measurement of zeolite acidity by ammonia temperature programmed desorption and FTi.r. spectroscopy techniques. Zeolites, 6(3), 185-194.doi:10.1016/0144-2449(86)90046-1

Lopes, C. W.; Villarroel-Rocha, J.; Silva, B. A.; Mignoni, M. L., \& Pergher, S. B. C. (2016). Synthesis and Characterization of Al-TON Zeolite Using a Dialkylimizadolium as Structure Directing Agent. Materials Research, 19, 1461-1468.doi:10.1590/1980-5373-MR-2016-0041

Luo, Y.; Wang, Z.; Jin, S.; Zhang, B.; Sun, H.; Yuan, X., \& Yang, W. (2016). Synthesis and crystal growth mechanism of ZSM-22 zeolite nanosheets. CrystEngComm, 18 (30), 5611-5615.doi:10.1039/C6CE00773B

Morimoto, N.; Takatsu, K., \& Sugimoto, M. (1983). Crystalline aluminosilicate and process for the production thereof (EP No 0121730B1)European Patent Office. https://patentimages.storage.googleapis.com/a8/11/ed/27c3bb8b195c42/EP0121730B1.pdf

Přech, J. Pizarro, P.; Serrano, D. P., \& Čejka, J. (2018). From 3D to 2D zeolite catalytic materials. Chemical Society Reviews, 47, 8263-8306. doi:10.1039/C8CS00370J

Qian, B.; Jiang, H.; Sun, Y., \& Long, Y. (2001). Affinity Study of Organics on Siliceous Ferrierite Type Zeolite. Langmuir, 17, 11191125.doi:10.1021/1a000835n

Quintela, P. H. L.; Lima, W. S.; Silva, B. J. B.; Silva, A. O. S., \& Rodrigues, M. G. F. (2021). Effect of the simultaneous presence of sodium and potassium cations on the hydrothermal synthesis of MCM-22 zeolite, Research, Society and Development, 10(14), e192101421744.doi:10.33448/rsd-v10i14.21744

Rahimi, N., \& Karimzadeh, R. (2011). Catalytic cracking of hydrocarbons over modified ZSM-5 zeolites to produce light olefins: A review. Applied Catalysis A: General, 398, 1-17.doi:10.1016/j.apcata.2011.03.009

Redekop, E. A.; Lazzarinia, A.; Bordigaa, S., \& Olsbye, U. (2020). A temporal analysis of products (TAP) study of C2-C4 alkene reactions with a welldefined pool of methylating species on ZSM-22 zeolite. Journal of Catalysis, 385, 300-312.doi:10.1016/j.jcat.2020.03.020

Rollmann, L. D.; Schlenker, J. L.; Lawton, S. L.; Kennedy, C. L.; Kennedy, G. J., \& Doren, D. J. (1999). On the Role of Small Amines in Zeolite Synthesis. The Journal of Physical Chemistry B, 103, 7175-7183.doi:10.1021/jp991913m

Rownaghi, A. A.; Rezaei, F., \& Hedlund, J. (2012). Selective formation of light olefin by n-hexane cracking over HZSM-5: influence of crystal size and acid sites of nano-and micrometer-sized crystals. Chemical Engineering Journal, 191, 528-533.doi:10.1016/j.cej.2012.03.023

Shin, J.; Jo, D., \& Hong, S. B. (2019). Rediscovery of the Importance of Inorganic Synthesis Parameters in the Search for New Zeolites. Accounts of Chemical Research, 52(5), 1419-1427.doi:10.1021/acs.accounts.9b00073

Silva, B. J. B.; Sousa, L. V.; Quintela, P. H. L.; Alencar Júnior, N. R.; Alencar, S. L.; Maciel, P. A. M.; Santos, J. R.; Sarmento, L. R. A.; Meneghetti, S. M. P., \& Silva, A. O. S. (2018). Preparation of ZSM-22 zeolite with hierarchical pore structure. Materials Letters, 218, 119-122.doi:10.1016/j.matlet.2018.01.146

Silva, B. J. B.; Sousa, L. V.; Sarmento, L. R. A.; Carvalho, R. P.; Quintela, P. H. L.; Pacheco, J. G. A.; Fréty, R., \& Silva, A. O. S. (2019). Effect of desilication on the textural properties, acidity and catalytic activity of zeolite ZSM-23 synthesized with different structure-directing agents. Microporous and Mesoporous Materials, 290, 109647.doi:10.1016/j.micromeso.2019.109647

Silva, B. J. B.; Melo, A. C. S.; Silva, D. S.; Sousa, L. V.; Quintela, P. H. L.; Alencar, S. L., \& Silva, A. O. S. (2020). Thermo-catalytic degradation of PE and UHMWPE over zeolites with different pore systems and textural properties. Cerâmica, 66, 379-385.doi:10.1590/0366-69132020663802948

Silva, B. J. B.; Sousa, L. V.; Sarmento, L. R. A.; Melo, A. C. S.; Silva, D. S.; Quintela, P. H. L.; Alencar, S. L., \& Silva, A. O. S. (2022). Effect of coke deposition over microporous and hierarchical ZSM-23 zeolite. Journal of Thermal Analysis and Calorimetry, 147, 3161-3170doi:10.1007/s10973-021-10740-

Sousa, L. V.; Silva, A. O. S.; Silva, B. J. B.; Teixeira, C. M. ; Arcanjo, A. P. ; Frety, R., \& Pacheco, J. G. A. (2017). Fast synthesis of ZSM-22 zeolite by the seed-assisted method of crystallization with methanol. Microporous and Mesoporous Materials, 254, 192-200.doi:10.1016/j.micromeso.2017.04.003

Thaker, A. H.; John, M.; Kumar, K.; Kasture, M. W.; Parmar, S.; Newalkar, B. L., \& Parikh, P. A. (2016). Hydroisomerization of Biomass Derived nHexadecane Towards Diesel Pool: Effect of Selective Removal External Surface Sites from Pt/ZSM-22. International Journal of Chemical Reactor Engineering, 14, 155-165. doi:10.1515/ijcre-2015-0049.

Treacy, M. M. J., \& Higgins, J. B. (2007). Collection of Simulated XRD Powder Patterns for Zeolites, Amsterdam: Elsevier.

Valyocsik, E. W. (1984). Synthesis of zeolite ZSM-22 (US Pat. No 4,902,406)U.S. Patent and Trademark Office. https://patentimages.storage.googleapis.com/b5/79/a5/6c83073872b042/US4902406.pdf

Verboekend, D.; Chabaneix, A. M.; Thomas, K.; Gilson, J. -P., \& Pérez-Ramirez, J. (2011). Mesoporous ZSM-22 zeolite obtained by desilication: peculiarities associated with crystal morphology and aluminium distribution. CrystEngComm, 13, 3408-3416.doi:10.1039/C0CE00966K 
Research, Society and Development, v. 11, n. 3, e6411326070, 2022

(CC BY 4.0) | ISSN 2525-3409 | DOI: http://dx.doi.org/10.33448/rsd-v11i3.26070

Verduijn, J. P., \& Martens, L. R. M. (1996). ZSM-22 zeolite (US Pat. No 5,783,168)U.S. Patent and Trademark Office. https://patentimages.storage.googleapis.com/a9/e3/ff/dfe25bc56bc62b/US5783168.pdf

Wang, Y.; Yokoi, T.; Namba, S.; Kondo, J. N., \& Tatsumi, T. (2015). Catalytic cracking of n-hexane for producing propylene on MCM-22 zeolites. Applied Catalysis A: General, 504, 192-202.doi:10.1016/j.apcata.2014.12.018.

Wang, X.; Zhang, X., \& Wang, Q. (2019). Fabrication of hierarchical ZSM-22 hollow sphere. Materials Letters, 244, 96-99.doi:10.1016/j.matlet.2019.01.153

Wen, H.; Zhou, Y.; Xie, J.; Long, Z.; Zhang, W. \& Wang, J. (2014). Pure-silica ZSM-22 zeolite rapidly synthesized by novel ionic liquid-directed dry-gel conversion. RSC Advances, 4, 49647-49654.doi:1039/C4RA07627C

Xu, S.; Zhang, X.; Cheng, D.-G.; Chen, F., \& Ren, X. (2018). Effect of hierarchical ZSM-5 zeolite crystal size on diffusion and catalytic performance of nheptane cracking. Frontiers of Chemical Science and Engineering, 12, 780-789.doi:10.1007/s11705-018-1733-8

Yu, J. (2007). Synthesis of zeolite. In: T. Cejka, H. Van Bekkum, A. Corma, F. Schuth (Eds.), Introduction to zeolite science and pratice (Studies in Surface Science and Catalysis, 168, p. 39-103). Amsterdam: Elsevier.doi:10.1016/S0167-2991(07)80791-9

Zhang, M.; Liu, X., \& Yan, Z. (2016). Soluble starch as in-situ template to synthesize ZSM-5 zeolite with intracrystal mesopores. Materials Letters, 164, 543546.doi:10.1016/j.matlet.2015.10.044

Zhang, X.; Cheng, D. G.; Chen, F., \& Zhan, X. (2018). The Role of External Acidity of Hierarchical ZSM-5 Zeolites in n-Heptane Catalytic Cracking. ChemCatChem,10(12), 2655-2663.doi:10.1002/cctc.201800086

Zhu, H.; Liu, Z.; Wang, Y. ; Kong, D.; Yuan, X., \& Xie, Z. (2008). Nanosized CaCO3 as hard template for creation of intracrystal pores within silicalite-1 crystal. Chemistry of Materials, 20, 1134-1139.doi:10.1021/cm071385o 